Full Paper

\title{
Cytotoxic Triterpenoid Saponins from the Roots of Platycodon grandiflorum
}

\section{Lin Zhang, Zhen-Huan Liu and Jing-Kui Tian*}

Institute of Modern Chinese Medicine, College of Pharmaceutical Sciences, Zhejiang University, Hangzhou 310058, P. R. China; Tel: (+86)-571-88208454; Fax: (+86)-571-88208446;

E-mail: zhanglin@zju.edu.cn (Zhang)

* Author to whom correspondence should be addressed; E-mail: tjk@zju.edu.cn

Received: 30 January 2007; in revised form: 2 April 2007 / Accepted: 3 April 2007 / Published: 23 April 2007

\begin{abstract}
Bioguided fractionation of the ethanol extracts obtained from Platycodon grandiflorum roots led to isolation of two new triterpenoid saponins, characterized as 3-O- $\beta$-D-glucopyranosyl-2 $\beta, 12 \alpha, 16 \alpha, 23,24$-pentahydroxyoleanane-28(13)-lactone $\quad$ (1) and 3-O- $\beta$-D-glucopyranosyl-(1 $\rightarrow 3)-\beta$-D-glucopyranosyl-2 $\beta, 12 \alpha, 16 \alpha, 23 \alpha$-tetrahydroxyoleanane28(13)- lactone (2) by 1D- and 2D-NMR and MS techniques, as well as chemical means. Both compounds showed cytotoxic activity against human ECA-109 cells.
\end{abstract}

Keywords: Platycodon grandiflorum, Triterpenoid saponins, cytotoxic activity.

\section{Introduction}

The roots of Platycodon grandiflorum have been used as a traditional Chinese medicine as an antiphlogistic, antitussive and expectorant [1]. This plant is well known to be abundant in triterpenoid saponins, and 55 such compounds have been isolated from the genus [2-18]. Platicodins have been found to exhibit varied biological activities, including anti-inflammatory, inhibition of prostaglandin $E_{2}$ production, inhibitory effects on pancreatic lipase, antiobesity and hypolipidemic effects, apoptosis induction, inhibition of inducible nitric oxide synthase and cyclooxygenase II, antitumor and immunomodulatory properties [19-32]. As part of our chemical studies on naturally occurring bioactive 
saponins, we report herein the isolation and characterization of two new saponins obtained from the ethanol extracts of the roots of this medicinal plant, as well as their cytotoxic activity.

\section{Results and Discussion}

\section{Structure Elucidation}

The combined 25\% EtOH and 75\% EtOH fractions eluted from a $\mathrm{D}_{101}$ macroporous resin column showed significant cytotoxic activity against human ECA-109 cells. Bioguided fractionation of the active fractions over silica gel eluting with a 95:5:0.5 50:50:5 $\mathrm{CHCl}_{3}-\mathrm{CH}_{3} \mathrm{OH}-\mathrm{H}_{2} \mathrm{O}$ gradient led to the isolation of two triterpenoid saponins 1-2 (Figure 1).

Figure 1. Structures of compounds 1 and 2.

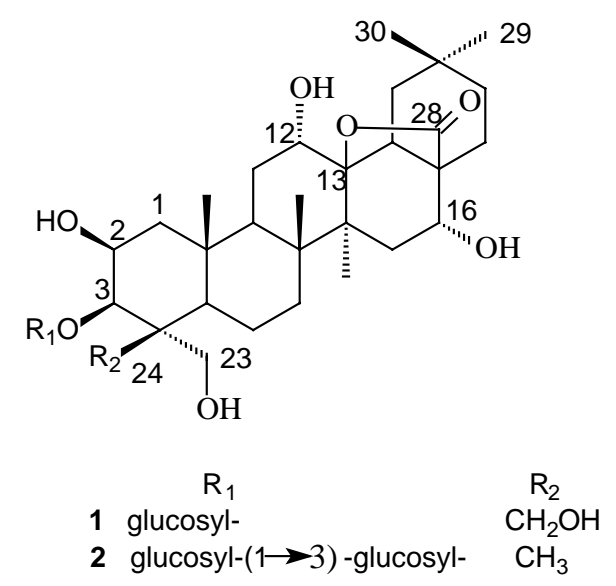

Compound 1 was obtained as a white powder with $\mathrm{mp} 222 \sim 223^{\circ} \mathrm{C}\left(\mathrm{CH}_{3} \mathrm{OH}\right)$ and $[\alpha]_{\mathrm{D}}^{20}:+11.76^{\circ}$ $\left(\mathrm{CH}_{3} \mathrm{OH} ; \mathrm{c}\right.$ 0.0170), that gave positive Libermann-Burchard and Molisch tests. The molecular formula was determined as $\mathrm{C}_{36} \mathrm{H}_{58} \mathrm{O}_{13}$, on the basis of its HRESIMS, which showed a $[\mathrm{M}+\mathrm{Na}]^{+}$quasimolecular ion peak at $\mathrm{m} / \mathrm{z} 721.3771$ (calcd. for $\mathrm{C}_{36} \mathrm{H}_{58} \mathrm{O}_{13} \mathrm{Na}$ 721.3775). The spectral features and physicochemical properties suggested 1 to be a triterpenoid saponin. Five methyl groups $(\delta 1.09,1.09$, 1.34, 1.52 and 1.94) were observed in the ${ }^{1} \mathrm{H}$-NMR spectrum. The ${ }^{13} \mathrm{C}$-NMR spectrum of 1 (Table 1) showed 36 carbons, which were classified into five methyls, 11 methylenes, 12 methines and eight quaternary carbons by DEPT experiments. In addition, the ${ }^{13} \mathrm{C}-\mathrm{NMR}$ spectrum displayed five $\mathrm{sp}^{3}$ carbons at $\delta$ 18.4, 20.2, 21.0, 24.6 and 33.4, two oxygenated methylene carbons at $\delta 63.3$ and 66.1, four oxygenated methine carbons at $\delta$ 69.2, 87.8, 66.1 and 72.1, and an oxygenated quaternary carbon at $\delta$ 92.8, attributable to the aglycone moiety. The NMR information thus indicated that $\mathbf{1}$ possessed a heptaoxygenated oleanane aglycone. D-glucose was detected by GC analysis after acidic hydrolysis and preparation of the corresponding thiazolidine derivative [33]. The presence of a $\beta$-glucose moiety was concluded based on a typical doublet peak of the anomeric proton of the glucose at $\delta 5.14(1 \mathrm{H}$, d, $J=7.7 \mathrm{~Hz}$ ) in the ${ }^{1} \mathrm{H}-\mathrm{NMR}$, as well as the ${ }^{13} \mathrm{C}-\mathrm{NMR}$ signals at $\delta 106.5,75.4,78.9,71.8,78.9$ and 62.7 of one glucose unit. In addition, the A-ring carbon signals of $\mathbf{1}$ were almost the same as those of a known compound, 3-O- $\beta$-D-glucopyranosylplatycodigenin methyl ester [10], indicating that the A-ring

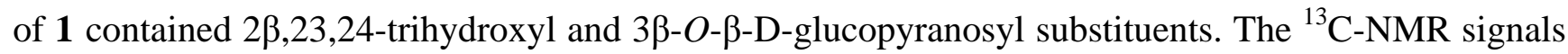
at $\delta 92.8$ and 178.1 revealed the existence of a lactone moiety in its structure. Based upon the above 
findings, it was deduced that 1 was a 3-O- $\beta$-D-glucopyranosyl-2 $\beta, 3 \beta, 23,24$-tetrahydroxy oleanane with another three oxygenated carbons, one $\left(\delta_{C} 92.8\right)$ of which was due to the lactone moiety.

Table 1. ${ }^{13} \mathrm{C}$ - (100 MHz) and ${ }^{1} \mathrm{H}-(400 \mathrm{MHz})$ NMR Data of 1 and 2 (pyridine- $\left.d_{5}\right){ }^{\mathrm{a}}$.

\begin{tabular}{|c|c|c|c|c|}
\hline \multirow[t]{2}{*}{ Position } & \multicolumn{2}{|r|}{1} & \multicolumn{2}{|r|}{2} \\
\hline & $\mathrm{C}$ & $\mathrm{H}(\mathrm{J}, \mathrm{Hz})$ & $\mathrm{C}$ & $\mathrm{H}(J \mathrm{~Hz})$ \\
\hline \multirow[t]{2}{*}{1} & 45.8 & $2.48, \mathrm{~d},(7.0)$ & 44.6 & $2.41, \mathrm{~d},(7.2)$ \\
\hline & & 2.87, d, (7.9) & & $2.85, \mathrm{~d},(7.6)$ \\
\hline 2 & 69.2 & $4.78, \mathrm{~m}$ & 70.8 & $4.78, \mathrm{~m}$ \\
\hline 3 & 87.8 & 4.68, m & 82.8 & 4.32, $\mathrm{m}$ \\
\hline 4 & 48.4 & & 43.2 & \\
\hline 5 & 46.1 & $0.92, \mathrm{dd},(6.6,7.0)$ & 47.9 & $0.83, \mathrm{dd},(6.4,6.9)$ \\
\hline 6 & 18.9 & & 17.4 & \\
\hline 7 & 35.3 & & 35.0 & \\
\hline 8 & 42.8 & & 42.8 & \\
\hline 9 & 45.3 & $2.20, \mathrm{dd},(7.2,7.8)$ & 45.1 & $2.22, \mathrm{dd},(7.3,8.0)$ \\
\hline 10 & 37.5 & & 36.7 & \\
\hline \multirow[t]{2}{*}{11} & 30.5 & $1.84, \mathrm{~m}$ & 30.2 & 1.87, $\mathrm{m}$ \\
\hline & & 2.37, m & & $2.40, \mathrm{~m}$ \\
\hline 12 & 66.1 & 4.54, m & 66.2 & $4.46, \mathrm{~m}$ \\
\hline 13 & 92.8 & & 92.6 & \\
\hline 14 & 43.3 & & 43.1 & \\
\hline 15 & 39.8 & 2.43, m & 39.8 & 2.37, m \\
\hline 16 & 72.7 & 4.51, $\mathrm{m}$ & 72.7 & $4.43, \mathrm{~m}$ \\
\hline 17 & 49.1 & & 49.0 & \\
\hline 18 & 53.3 & & 53.2 & \\
\hline 19 & 40.8 & & 40.7 & \\
\hline 20 & 32.0 & & 31.9 & \\
\hline 21 & 35.8 & $2.54, \mathrm{dd},(7.0,7.6)$ & 35.7 & $2.48, \mathrm{dd},(7.0,7.5)$ \\
\hline \multirow[t]{2}{*}{22} & 29.0 & 2.07, dd, $(7.0,15.5)$ & 29.0 & $2.02, \mathrm{dd},(7.0,15.0)$ \\
\hline & & $2.26, \mathrm{dd},(7.6,15.5)$ & & $2.30, \mathrm{dd},(7.5,15.0)$ \\
\hline \multirow[t]{2}{*}{23} & 63.3 & $4.30, \mathrm{~m}$ & 65.0 & $4.10, \mathrm{~m}$ \\
\hline & & 4.86, $\mathrm{m}$ & & $4.52, \mathrm{~m}$ \\
\hline \multirow[t]{2}{*}{24} & 66.1 & $4.24, \mathrm{~m}$ & 14.9 & $1.31, \mathrm{~s}$ \\
\hline & & $4.75, \mathrm{~m}$ & & \\
\hline 25 & 20.2 & $1.52, \mathrm{~s}$ & 18.8 & $1.51, \mathrm{~s}$ \\
\hline 26 & 18.4 & $1.34, \mathrm{~s}$ & 18.5 & $1.30, \mathrm{~s}$ \\
\hline 27 & 21.0 & $1.94, \mathrm{~s}$ & 21.1 & $1.89, \mathrm{~s}$ \\
\hline 28 & 178.1 & & 178.1 & \\
\hline 29 & 33.4 & $1.09, \mathrm{~s}$ & 33.4 & $1.01, \mathrm{~s}$ \\
\hline 30 & 24.6 & 1.09, s & 24.5 & $1.01, \mathrm{~s}$ \\
\hline $1^{\prime}$ & 106.5 & $5.14, d,(7.7)$ & 105.6 & $5.14, \mathrm{~d},(7.0)$ \\
\hline $2^{\prime}$ & 75.4 & 3.80 & 75.3 & 3.82 \\
\hline
\end{tabular}


Table 1. Cont.

\begin{tabular}{lllll}
\hline $3^{\prime}$ & 78.9 & 4.05 & 88.8 & 3.93 \\
$4^{\prime}$ & 71.8 & 3.96 & 69.7 & 3.97 \\
$5^{\prime}$ & 78.9 & 3.87 & 77.9 & 3.86 \\
$6^{\prime}$ & 62.7 & $4.04,4.18$ & 62.6 & $4.05,4.19$ \\
$1^{\prime \prime}$ & & & 106.0 & $5.22, \mathrm{~d},(6.6)$ \\
$2^{\prime \prime}$ & & & 75.6 & 3.77 \\
$3^{\prime \prime}$ & & & 78.8 & 4.02 \\
$4^{\prime \prime}$ & & & 71.7 & 3.94 \\
$5^{\prime \prime}$ & & & 78.3 & 3.85 \\
$6^{\prime \prime}$ & & & 62.3 & $3.99,4.15$ \\
\hline
\end{tabular}

${ }^{a}$ Chemical shifts $(\delta)$ given in ppm

The positions of the other substituents were determined by its ${ }^{1} \mathrm{H}-{ }^{1} \mathrm{H}$ COSY (Figure 2) and HMBC (Figure 3) spectra and literature data. The correlations between $25-\mathrm{CH}_{3}\left(\delta_{H} 1.52\right)$ and $\delta_{C} 45.8(\mathrm{C}-1)$, 45.3 (C-9) could be observed in the HMBC spectrum of 1 . Whilst $\delta_{H} 2.20$ (1H, dd, J=7.2, $7.8 \mathrm{~Hz}, \mathrm{H}-9$ ) had correlations in the ${ }^{1} \mathrm{H}-{ }^{1} \mathrm{H}$ COSY spectrum with $\delta_{H} 2.37$ and 1.84 , corresponding to the same carbon signal at $\delta_{C} 30.5(\mathrm{C}-11)$ on the basis of its HMQC spectrum. A second methyl signal at $\delta_{H} 1.34$ $\left(26-\mathrm{CH}_{3}\right)$ could also be seen in the HMBC spectrum to correlate with $\delta_{C} 45.3$ (C-9), 35.3 (C-7), 42.8 (C-8) and 43.3 (C-14), which confirmed the 26- $\mathrm{CH}_{3}$ location. Thus another methyl signal correlating with C-8 $\left(\delta_{C} 42.8\right)$ at $\delta_{H} 1.94$ in the HMBC spectrum must be located at C-27.

The HMBC spectrum also displayed correlations of the 27- $\mathrm{CH}_{3}\left(\delta_{H} 1.94\right)$ with $\delta_{C} 39.8(\mathrm{C}-15)$ and 92.8 (C-13), indicating that the oxygenated carbon signal due to the lactone moiety $\left(\delta_{C} 92.8\right)$ could be assigned to $\mathrm{C}-13$. The HMBC correlations between the two methyl signals $\left(\delta_{H} 1.09\right)$ and $\delta_{C} 35.8$ (C-21), 40.8 (C-19), 32.0 (C-20), 24.6 (C-30) and 33.4 (C-29), respectively, indicated that these two methyl groups were located at the same carbon with the signal at $\delta_{C} 32.0(\mathrm{C}-20)$. The proton signal at $\delta_{H} 2.54$ (H-21) had correlations with $\delta_{H} 2.26$ and 2.07 (both $\mathrm{H}-22$ ) in the ${ }^{1} \mathrm{H}-{ }^{1} \mathrm{H}$ COSY spectrum. In addition, the correlations between $\delta_{H} 2.07(\mathrm{H}-22)$ and $\delta_{C} 178.1(\mathrm{C}-28)$ could also be observed in its HMBC spectrum, indicating that the carbonyl group of the lactone was located at C-28. Thus, it could be deduced that the lactone should be $28 \rightarrow 13$, a fact that was also be proved by comparison with the known oleanderolide-(lactone $28 \rightarrow 13$ ) [34]. The proton signal at $\delta_{H} 4.54$, corresponding to an oxygenated methine carbon signal at $\delta_{C} 66.1$ in the HMQC experiment, was observed in the HMBC to correlate with both $\delta_{C} 92.8(\mathrm{C}-13)$ and $45.3(\mathrm{C}-9)$, showing that this proton should be located at C-12 and a hydroxyl group substitutent must exist at C-12. Correlations between $\mathrm{H}-15\left(\delta_{H} 2.43\right)$ and $\delta_{H} 4.51$ (H-16) corresponding to the oxygenated methine carbon signal at $\delta_{C} 72.7$ could be seen from the ${ }^{1} \mathrm{H}-{ }^{1} \mathrm{H}$ COSY data and were confirmed by the HMQC spectrum, indicating another hydroxyl group was located at C-16.

The configurations of the12,16-OH were determined by the NOESY spectrum (Figure 2). The presence of a NOESY effect between $\delta_{H} 4.54(\mathrm{H}-12)$ and $\delta_{H} 1.34\left(26 \beta-\mathrm{CH}_{3}\right)$, but the absence of any NOESY effect between $\delta_{H} 4.54(\mathrm{H}-12)$ and $\delta_{H} 1.94\left(27 \alpha-\mathrm{CH}_{3}\right)$ indicated the $\alpha$-configuration of 12-OH. In addition, the same result was also obtained in the NOESY spectrum for $\mathrm{H}-16$ at $\delta_{H} 4.51$. Therefore, the structure of $\mathbf{1}$ was identified as 3-O- $\beta$-D-glucopyranosyl-2 $\beta, 12 \alpha, 16 \alpha, 23,24$-pentahydroxyoleanane- 28(13)-lactone, which was a new compound. 
Figure 2. Key correlations in the ${ }^{1} \mathrm{H}-{ }^{1} \mathrm{H}$ COSY and NOESY spectra of $\mathbf{1}$.

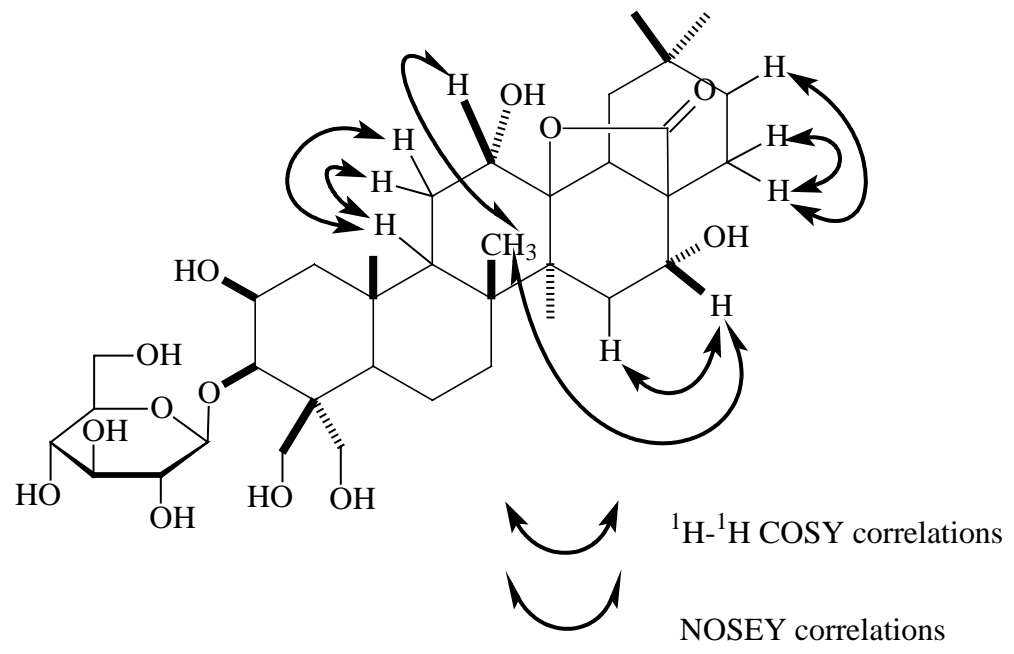

Compound 2 was isolated as white powder with mp $212 \sim 213^{\circ} \mathrm{C}\left(\mathrm{CH}_{3} \mathrm{OH}\right)$ and $[\alpha]_{\mathrm{D}}^{20}:+31.71^{\circ}$ $\left(\mathrm{CH}_{3} \mathrm{OH} ; \mathrm{c}\right.$ 0.0410), giving positive Libermann-Burchard and Molish test results. The $[\mathrm{M}+\mathrm{Na}]^{+}$quasimolecular ion peak at $\mathrm{m} / \mathrm{z} 867.4352$ (calcd. for $\mathrm{C}_{42} \mathrm{H}_{68} \mathrm{O}_{17} \mathrm{Na}$ 867.4354). The ${ }^{1} \mathrm{H}-\mathrm{NMR}$ spectrum gave six methyl groups $(\delta 1.01,1.01,1.30,1.31,1.51$ and 1.89$)$, corresponding to six sp ${ }^{3}$ carbons at $\delta 14.9$, 18.5, 18.8, 21.1, 24.5 and 33.4, respectively in the ${ }^{13} \mathrm{C}$-NMR spectrum. In addition, all spectral features and physicochemical properties revealed that 2 might also be a triterpenoid saponin. The ${ }^{13} \mathrm{C}-\mathrm{NMR}$ spectrum of $\mathbf{2}$ showed aglycone signals that were broadly similar to those of $\mathbf{1}$, except those attributable to the A-ring carbons (see Table 1). Consequently, 2 was assumed to have an aglycone with some differences in the A-ring compared to $\mathbf{1}$. Among the A-ring carbon signals of $\mathbf{2}$, it could be observed that they were almost identical to those of methyl 3-O- $\beta$-laminaribiosylpolygalacate [10], suggesting that $\mathbf{2}$ had the same A-ring moiety as the latter. Thus, the aglycone of $\mathbf{2}$ was deduced to be $2 \beta, 3 \beta, 12 \alpha, 16 \alpha, 23 \alpha$-pentahydroxyoleanane-28(13)-lactone. The sugar sequences of the disaccharide chain were determined by its spectrometric data. The negative mode ESI-MS, showing a quasi-molecular ion peak at $\mathrm{m} / \mathrm{z} 843[\mathrm{M}-\mathrm{H}]^{-}$, and the fragment ion peaks at $\mathrm{m} / \mathrm{z} 681$ [M-162 (glucose)-H]', 519 [681-162 (glucose)]', indicated the presence of two glucose units. The ${ }^{1} \mathrm{H}-\mathrm{NMR}$ of 2 displayed two sugar anomeric protons at $\delta_{H} 5.14\left(1 \mathrm{H}, \mathrm{d}, J=7.0 \mathrm{~Hz}, \mathrm{H}-1^{\prime}\right)$ and $\delta_{H} 5.22(1 \mathrm{H}, \mathrm{d}, J=6.6 \mathrm{~Hz}$, $\left.\mathrm{H}-1^{\prime \prime}\right)$, respectively, coupling to two groups of sugar carbon signals in the ${ }^{13} \mathrm{C}-\mathrm{NMR}$ at $\delta_{\mathrm{C}} 105.6\left(\mathrm{C}-1^{\prime}\right)$, 75.3 (C-2'), 88.8 (C-3'), $69.7\left(\mathrm{C}-4^{\prime}\right), 77.9\left(\mathrm{C}-5^{\prime}\right), 62.6\left(\mathrm{C}-6^{\prime}\right)$ and $\delta_{\mathrm{C}} 106.0\left(\mathrm{C}-1^{\prime \prime}\right), 75.6\left(\mathrm{C}-2^{\prime \prime}\right), 78.8$ (C-3"), 71.7 (C-4"), 78.3 (C-5"), 62.3 (C-6") (Table 1). These findings confirmed the presence of two $\beta$-glucose units in this molecule. D-glucose was also detected by GC analysis after acid hydrolysis and preparation of the thiazolidine derivatives. The spin-systems associated with saccharides were identified by a HMQC-TOCSY experiment with the aid of a ${ }^{1} \mathrm{H}-{ }^{1} \mathrm{HCOSY}$ spectrum. All ${ }^{1} \mathrm{H}-$ and ${ }^{13} \mathrm{C}-\mathrm{NMR}$ signals of the sugar moieties were assigned by HMQC experiment. The HMBC spectrum displayed correlations between the anomeric proton signal of the first D-glucose at $\delta_{H} 5.14\left(\mathrm{H}-1^{\prime}\right)$ and $\mathrm{C}-3$ of the aglycone at $\delta_{C} 82.8$, suggesting the connection of this glucose at C-3. In addition, downfield chemical shifting of $\mathrm{C}-3^{\prime}$ by $\delta_{C} 88.8$ together with the correlation between the anomeric proton signal of the second D-glucose at $\delta_{H} 5.22\left(\mathrm{H}-1^{\prime \prime}\right)$ and $\mathrm{C}-3^{\prime}\left(\delta_{C} 88.8\right)$ were indicative of the existence of $\beta$-D-glucopyranosyl-( $1 \rightarrow 3)-\beta$-D-glucopyranosyl disaccharide chain. Therefore, the structure of 2 was elucidated as $3-O-\beta$-D-glucopyranosyl-( $1 \rightarrow 3)-\beta$-D-glucopyranosyl-2 $\beta, 12 \alpha, 16 \alpha, 23 \alpha$-tetrahydroxyloleanane-28(13)-lactone, which was also a new compound. 
Figure 3. Key correlations in the HMBC spectrum of 1.

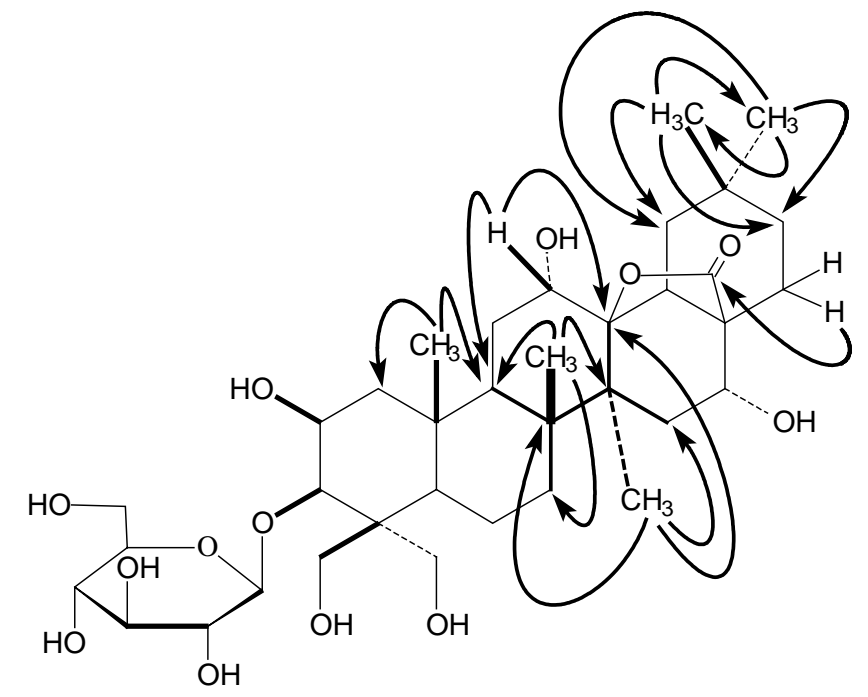

Cytotoxic activity

The two new saponins identified in the present study were examined for their cytotoxic activity against the human Eca-109 cell line. Topotecan ( $\mathrm{IC}_{50} 0.032 \mu \mathrm{g} / \mathrm{mL}$ ) was used as a standard in the cytotoxic assay. The saponins exhibited cytotoxicity against human Eca-109 and gave $\mathrm{IC}_{50}$ values of $0.649 \mu \mathrm{g} / \mathrm{mL}(\mathbf{1})$ and $0.503 \mu \mathrm{g} / \mathrm{mL}(2)$, respectively.

\section{Conclusions}

Two new triterpenoid saponins, characterized as 3-O- $\beta$-D-glucopyranosyl-2 $\beta, 12 \alpha, 16 \alpha, 23,24-$ pentahydroxy-oleanane-28(13)-lactone (1) and 3-O- $\beta$-D-glucopyranosyl-(1 $\rightarrow 3)-\beta$-D-glucopyranosyl$2 \beta, 12 \alpha, 16 \alpha, 23 \alpha$-tetrahydroxy-oleanane-28(13)-lactone (2). Each of them shows cytotoxic activity against human ECA-109 cells.

\section{Experimental}

General

All melting points were determined using a Fisher Johns apparatus and are uncorrected. Optical rotations were measured on a Perkin-Elmer 241 polarimeter. 1D- and 2D-NMR spectra were recorded on a Bruker 400 spectrometer. The ESIMS and HRESIMS were recorded in a LCQ DECA XP plus spectrometer. An Agilent 1100 series HPLC was used with a Zorbax SB-C 18 preparative column. GC-MS was performed using a Shimadzu QP5050A instrument. Thin-layer chromatography employed precoated silica gel plates (Qingdao Haiyang). For column chromatography, silica gel (Qingdao Haiyang), $\mathrm{D}_{101}$ macroporous resin (Tianjin Nankai) and Sephadex LH-20 (Pharmacia) were used. 


\section{Plant Material}

Roots of P. grandiflorum were collected from Hangzhou in the Zhejiang province of China and identified by Dr Lin Zhang (Institute of Modern Traditional Chinese Medicine, College of Pharmaceutical Sciences, Zhejiang University). A voucher specimen was deposited at the Institute of Modern Traditional Chinese Medicine, College of Pharmaceutical sciences, Zhejiang University, P.R. China.

\section{Extraction and Isolation}

Dried roots of $P$. grandiflorum (10 kg) were extracted twice with $95 \% \mathrm{EtOH}$ and $50 \% \mathrm{EtOH}$, and the extracts were combined, then concentrated. The concentrates were submitted to $\mathrm{D}_{101}$ macroporous resin column chromatography eluting successively with water, 25\% EtOH, 75\% EtOH and 95\% EtOH. The 25\% EtOH and 75\% EtOH fractions were combined and the solvent removed under reduced pressure to give a crude extract (197 g). The extract was chromatographed over silica gel, and eluted with a $\mathrm{CHCl}_{3}-\mathrm{CH}_{3} \mathrm{OH}-\mathrm{H}_{2} \mathrm{O}$ gradient (95:5:0.5 50:50:5) to give 50 fractions. Fractions 24 26 $\left(\mathrm{CHCl}_{3}-\right.$ $\mathrm{CH}_{3} \mathrm{OH}-\mathrm{H}_{2} \mathrm{O}$, 80:20:2) were submitted to repeated column chromatography over silica gel with $\mathrm{CHCl}_{3}-\mathrm{CH}_{3} \mathrm{OH}-\mathrm{H}_{2} \mathrm{O}$ and further purified on Sephadex $\mathrm{LH}-20$ eluting with $\mathrm{CH}_{3} \mathrm{OH}$ to give compounds 1 (18 mg) and 2 (20 mg). For ${ }^{1} \mathrm{H}$ - and ${ }^{13} \mathrm{C}-\mathrm{NMR}$ data see Table 1.

\section{Acid Hydrolysis}

Compound 1 and 2 (each $5 \mathrm{mg}$ ) were dissolved in water (100 mL) and 2M HCl (100 mL) and heated at $100{ }^{\circ} \mathrm{C}$ for $1 \mathrm{~h}$. The water was passed through an Amberlite IRA-60E column $(6 \times 50 \mathrm{~mm})$ and the eluates were concentrated. The residues were dissolved in pyridine ( $25 \mathrm{~mL}$ ) and stirred with $\mathrm{D}$ cysteine methyl ester $(4.0 \mathrm{mg})$ for $1.5 \mathrm{~h}$ at $60{ }^{\circ} \mathrm{C}$. To the reaction mixture, hexamethyldisilazane $(10$ $\mathrm{mL})$ and trimethylsilyl chloride $(10 \mathrm{~mL})$ were added and the mixture was stirred for $30 \mathrm{~min}$ at $60{ }^{\circ} \mathrm{C}$. The supernatants were then analyzed by GC [Column: DB-50, $25 \mathrm{~mm} \times 30 \mathrm{~m}$, column temperature; 230 ${ }^{\circ} \mathrm{C}$; carrier gas: $\mathrm{N}_{2}$, retention time D-Glc (16.4 min), L-Glc (16.0 min). From the new saponins, only D-glucose was detected.

\section{Cytotoxicity Assays}

Viability of ECA-109 cells in the presence or absence of experimental fractions or compounds was determined using the standard sulforhodamine B (SRB) assay as described previously [35]. Briefly, assays were carried out in 96-well plates. 4,000 cells/well were plated in media containing 5\% FBS and were allowed to attach overnight. The cells were treated with $200 \mu \mathrm{L}$ of media containing either $0.06 \%$ DMSO alone (control) or varying concentrations of test specimens dissolved in DMSO. The plates were incubated at $37{ }^{\circ} \mathrm{C}$ in a humidified incubator containing $5 \% \mathrm{CO}_{2}$. The cells were fixed after 3 days by incubation in cold 50\% TCA for $1 \mathrm{~h}$ at $4{ }^{\circ} \mathrm{C}$ in the dark. The media and TCA were removed and the plates were rinsed five times with water and then air-dried. The cells were stained by addition of $0.4 \%$ SRB (Sigma, St. Louis, MO) in 1\% acetic acid (50 $\mu \mathrm{L}$ ) for $5 \mathrm{~min}$. The stain was removed and the cells were washed five times with $1 \%$ acetic acid, air-dried, and $150 \mu \mathrm{L}$ of $10 \mathrm{mM}$ unbuffered Tris 
was then added to each well to dissolve the dye. The plates were shaken for 5 min until the dye was uniformly distributed and then read on an Emax Precision Plate Reader (Molecular Devices, Sunnyvale, CA) at $570 \mathrm{~nm}$. Media were used as the blank for these assays.

\section{Acknowledgements}

The authors expressed their gratitude to Mrs. Li-Ping Shi (Shanghai Institute of Organic Chemistry, China Academy of Sciences) for obtaining the $400 \mathrm{MHz}$ NMR data. We were also grateful to Mr. Yu-Feng Zhang (Department of Chinese Medicine Science and Engineering, Zhejiang University) and Mr. Yuan-Bo Dai (Department of Chemistry, College of Science, Zhejiang University) for obtaining the ESI and HRESI data.

\section{References}

1. Pharmacopoeia of the People's Republic of China; Chemical Industry Press: Beijing, 2005; Vol. I, p. 196.

2. Akiyama, T.; Iitaka, Y.; Tanaka, O. Structure of platicodigenin, a saogenin of Platycodon grandiflorum A. De Candolle. Tetrahedron Lett. 1968, 53, 5577-5580.

3. Fu, W.W.; Dou, D.Q.; Shimizu, N.; Takeda, T.; Fu, R.; Pei, Y.H.; Chen, Y.J. Studies on the chemical constituents from the roots of Platycodon grandiflorum. J. Nat. Med. 2006, 60, 68-72.

4. Fu, W.W.; Hou, W.B.; Dou, D.Q.; Hua, H.M.; Gui, M.H.; Fu, R.; Chen, Y.J.; Pei, Y.H. Saponins of polygalacic acid type from Platycodon grandiflorum. Acta Pharm. Sin. 2006, 41, 358-360.

5. Fu, W.W.; Shimizu, N.; Dou, D.Q.; Takeda, T.; Fu, R.; Pei, Y.H.; Chen, Y.J. Five new triterpenoid saponins from the roots of Platycodon grandiflorum. Chem. Pharm. Bull. 2006, 54, 557-560.

6. Fu, W.W.; Shimizu, N.; Takeda, T.; Dou, D.Q.; Chen, B.H.; Pei, Y.H.; Chen, Y.J. New A-ring lactone triterpenoid saponins from the roots of Platycodon grandiflorum. Chem. Pharm. Bull. 2006, 54, 1285-1287.

7. He, Z.D.; Qiao, C.F.; Han, Q.B.; Wang, Y.; Ye, W.C.; Xu, H.X. New triterpenoid saponins from the roots of Platycodon grandiflorum. Tetrahedron 2005, 61, 2211-2215.

8. Ishii, H.; Tori, K.; Tozyo, T.; Yoshimura, Y. Structures of Polygalacin-D and $-\mathrm{D}_{2}$, and Their Monoacetates, Saponins isolated from Platycodon grandiflorum A. DC., determined by Carbon13 Nuclear Magnetic Resonance Spectroscopy. Chem. Pharm. Bull. 1978, 26, 674-677.

9. Ishii, H.; Tori, K.; Tozyo, T.; Yoshimura, Y. Structures of platycodin- $\mathrm{D}_{3}$, platyconic acid -A, and their derivatives, saponins isolated from roots of Platycodon grandiflorum A. De Candolle, determined by carbon-13 NMR spectroscopy. Chem. Lett. 1978, 719-722.

10. Ishii, H.; Tori, K.; Tozyo, T.; Yoshimura, Y. Saponins from roots of Platycodon grandiflorum. Part 1. Structure of prosapogenins. J. Chem. Soc. Perkin Trans. 1 1981, 1928-1933.

11. Ishii, H.; Tori, K.; Tozyo, T.; Yoshimura, Y. Saponins from roots of Platycodon grandiflorum. Part 2. Isolation and structure of new triterpene glycosides. J. Chem. Soc. Perkin Trans. 1984, 661-668. 
12. Kim, Y.-S.; Kim, J.-S.; Choi, S.-U.; Kim, J.-S.; Lee, H.-S.; Roh, S.-H.; Jeong, Y.-C.; Kim, Y.-K.; Ryu, S.-Y. Isolation of a new saponin and cytotoxic effect of saponins from the root of Platycodon grandiflorum on human tumor cell lines. Planta Med. 2005, 71, 566-568.

13. Konishi, T.; Rada, A.; Shoji, J.; Kasai, R.; Tanaka, O. The Structures of Platcodin A and C, Monoacetylated Saponins of the Roots of Platycodon grandiflorum A. DC. Chem. Pharm. Bull. 1978, 26, 668-670.

14. Kubota, T.; Kitatani, H.; Hinoh, H. Structure of platycogenic acids A, B and C Further Trierpenoid Constituents of Platycodon grandiflorum. J. Chem. Soc. D. 1969, 22, 1313-1314.

15. Nikaido, T.; Koike, K.; Mitsunaga, K.; Saeki, T. Tirterpenoid saponins from root of Platycodon grandiflorum. Nat. Med. 1998, 52, 54-59.

16. Nikaido, T.; Koike, K.; Mitsunaga, K.; Saeki, T. Two New Triterpenoid Saponins from Platycodon grandflorum. Chem. Pharm. Bull. 1999, 47, 903-904.

17. Tada, A.; Kaneiwa, Y.; Shoji, J.; Shibata, S. Studies on the saponins of the Roots of Platycodon grandiflorum A. De Candolle. I. Isolation and the Stricture of Platycodin-D. Chem. Pharm. Bull. 1975, 23, 2965-2972.

18. Fu, W.W.; Dou, D.Q.; Zhao, C.J.; Shimizu, N.; Pei, Y.P.; Pei, Y.H.; Takeda, T.; Chen, Y.J.; Takeda, T. Triterpenoid saponins from Platycodon grandiflurum. J. Asia Nat. Prod. Res. 2007, 9, 35-40.

19. Kim, Y.-P.; Lee, E.-B.; Kim, S.-Y.; Li, D.-W.; Ban, H.-S.; Lim, S.-S.; Shin, K.-H.; Ohuchi, K. Inhibition of Prostaglandin E2 Production by Platycodin D Isolated from the Root of Platycodon grandiflorum. Planta Med. 2001, 67, 362-364.

20. Kim, J.-Y.; Hwang, Y.-P.; Kim, D.-H.; Han, E.-H.; Chung, Y.-C.; Roh, S.-H.; Jeong, H.-G. Inhibitory effect of the saponins derived from roots of Platycodon grandiflorum on carrageenaninduced inflammation. Biosci. Biotech. Biochem. 2006, 70, 858-864.

21. Kim, J.-Y.; Kim, D.-H.; Kim, H.-G.; Song, G.-Y.; Chung, Y.-C.; Roh, S.-H.; Jeong, H.-G. Inhibition of tumor necrosis factor-alpha-induced expression of adhesion molecules in human endothelial cells by the saponins derived from roots of Platycodon grandiflorum. Toxicol. Appl. Pharmacol. 2006, 210, 150-156.

22. Kubo, A.; Sasada, M.; Yamamoto, K.; Nishiyama, H.; Nishimura, T.; Nakamura, T.; Uchino, H. Immune Pharmacological Studies on Platycodi Radii (I). Effect on the Phagocytosis in Mouse. Shoyakugaku Zasshi 1986, 40, 367-374.

23. Lee, K.-J.; Kim, J.-Y.; Choi, J.-H.; Kim, H.-G.; Chung, Y.-C.; Roh, S.-H.; Jeong, H.-G. Inhibition of tumor invasion and metastasis by aqueous extract of the radix of Platycodon grandiflorum. Food Chem. Toxico. 2006, 44, 1890-1896.

24. Shin, C.-Y.; Lee, W.-J.; Lee, E.-B.; Choi, E.-Y.; Ko, K.-H. Platycodin D and $\mathrm{D}_{3}$ Increase Airway Mucin Release in vivo and in vitro in Rats and Hamsters. Planta Med. 2002, 68, 221-225

25. Takagi, K.; Lee, E.-B. Pharmacological Studies on Platycodon grandiflorum A.DC. I. Acute Toxicity and Central Depressant Activity of Crude Platycodin. Yakugaku Zasshi 1972, 92, 951960.

26. Yokoyama, H.; Hiai, S.; Oura, H. Rat Plasma Corticosterone Secretion- inducing Activities of Total Saponin and Prosapogenin Methyl Esters from the Roots of Platycodon grandiflorum A.DC. Yakugaku Zasshi 1982, 102, 1191-1194. 
27. Xu, B.J.; Han, L.K.; Zheng, Y.N.; Lee, J.-H.; Sung, C.-K. In vitro inhibitory of triterpenoidal saponins from platycodi radix on pancreatic lipase. Arch. Pharm. Res. 2005, 28, 180-185.

28. Zhao, H.L.; Kim, Y.-S. Determination of kinetic properties of platycodin D for the inhibition of pancreatic lipase using a 1,2-diglyceride-based colorimetric assay. Arch. Pharm. Res. 2004, 27, 1048-1052.

29. Zhao, H.L.; Sim, J.-S.; Shim, S.H.; Ha, Y.W.; Kang, S.S.; Kim, Y.S. Antiobese and hypolipidemic effects of platicodin saponins in diet-induced obese rats: evidences for lipase inhibition and calorie intake restriction. Int. J. Obesity 2005, 29, 983-990.

30. Zhao, H.L.; Cho, K.-H.; Ha, Y.W.; Jeong, T.-S.; Lee, W.S.; Kim, Y.S. Cholesterol-lowering effect of platycodin D in hypercholesterolemic ICR mice. Eur. J. Pharmacol. 2006, 537, 166-173.

31. Ahn, K.S.; Hahn, B.-S.; Kwack, K.B.; Lee, E.B.; Kim, Y.S. Platycodin D-induced apoptosis through nuclear factor- $\mathrm{B}$ activation in immortalized keratinocytes. Eur. J. Pharmacol. 2006, 537, $1-11$.

32. Ahn, K.S.; Noh, E. J.; Zhao, H.L.; Jung, S.H.; Kang, S.S.; Kim, Y.S. Inhibition of inducible nitric oxide synthase and cyclooxygenase II by Platycodon grandiflorum saponins via suppression of nuclear factor- $\kappa$ B activation in RAW 264.7 Life Sci. 2005, 76, 2315-2328.

33. Hara, S.; Okabe, H.; Mihashi, K. Separation of aldose enantiomers by gas-liquid chromatography. Chem. Pharm. Bull. 1986, 34, 1843-1844.

34. Li, W.-F.; Zhang, S.-J.; Li, N.; Wang, M.-Z.; Sakai, J.; Hasegawa, T.; Mitsui, T.; Kataoka, T.; Oka, S.; Kiuchi, M.; Hirose, K.; Ando, M. Three new triterpenes from Nerium oleander and biological activity of the isolated compounds. J. Nat. Prod. 2005, 68, 198-206

35. Guido, F.; Pauli. The cardenolide of Speirantha convallarioides. Planta Med. 1995, 61,162 -166.

Sample availability: Available from the author.

(C) 2007 by MDPI (http://www.mdpi.org). Reproduction is permitted for noncommercial purposes. 